\title{
Nutritional aspects of amino acid metabolism
}

\section{3. ${ }^{*}$ The effects of diabetes on blood and liver amino acid concentrations in the rat}

\author{
By D. L. BLOXAM $\uparrow$ \\ (Beit Memorial Fellow) \\ Department of Biochemistry, University College, London \\ (Received 6 October 1970-Accepted 3 September 1971)
}

\begin{abstract}
I. Measurements of the concentrations of amino acids in the plasma of blood from the portal vein and hepatic vein in the livers of rats made diabetic with streptozotocin or alloxan and starved for $\mathrm{I} d$ were compared with similar measurements from normal rats starved for $\mathrm{I} d$.

2. The concentrations of many of the amino acids in the blood plasma were lower in the streptozotocin diabetic rats than in the normal animal while the liver concentrations tended to be increased. This suggests that there is enhanced concentration of these amino acids by the liver in diabetics, as is also found in starvation, which is probably due to factors other than the direct absence of insulin.

3. The direction of flow of the groups of amino acids into and out of the liver was unchanged in the diabetic compared with the normal rat except that the output of tryptophan was abolished, and that of the branched-chain group was abolished in alloxan diabetes though apparently enhanced in streptozotocin diabetes. The rates of movement of amino acids in both directions appeared to be increased in the streptozotocin diabetic animals.

4. The changed amino acid pattern in the alloxan diabetic rats was to some extent similar to that of the streptozotocin diabetic rats but the changes were more difficult to interpret, perhaps because of side-effects of alloxan on tissues including liver.
\end{abstract}

The previous paper (Bloxam, 1972) showed that the liver exerts a strong influence on amino acid availability in the normal rat, and changes were observed in amino acid pattern in blood and liver and in flows of amino acids to and from the liver during starvation. In view of the suggestion that changes in the distribution of amino acids between tissues are mediated by effects on the tissues of hormones such as insulin, glucocorticoids and glucagon (Manchester, 1970; Munro, 1964; Christensen, 1964), experiments were carried out to find the effects of the altered hormone balance of diabetes on the influence of the liver on blood amino acid concentrations. The effects of diabetes induced with streptozotocin were compared with those produced with alloxan because metabolic differences have been found between these two types of diabetes (Mansford \& Opie, 1968; Beloff-Chain \& Rookledge, 1968).

\section{METHODS}

Animals. Male Wistar rats were used in this work and fed as described previously (Bloxam, I972). Diabetes was induced in rats weighing 250-290 g either by intravenous injection of streptozotocin (Upjohn), $60 \mathrm{mg} / \mathrm{kg}$ body-weight (administered as

* Paper no. 2: Br. J. Nutr. (1972), 27, 233.

$\uparrow$ Present address: Department of Pathology, University of Toronto, Canada. 


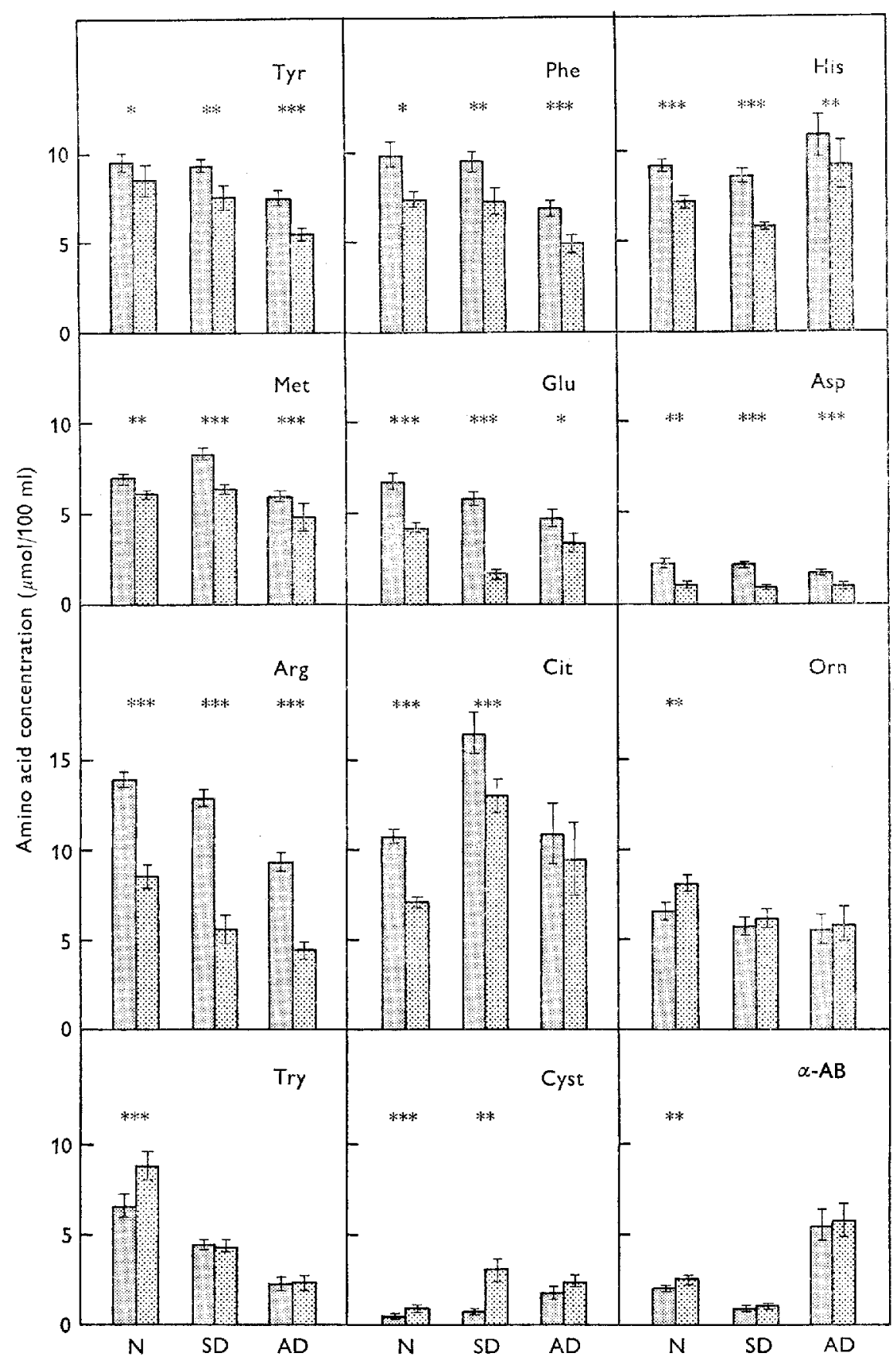

Fig. $x$. Concentrations of the amino acids in the plasma of portal (shaded) and hepatic (stippled) venous blood from streptozotocin diabetic rats (SD) and alloxan diabetic rats (AD) compared with the values for normal rats $(\mathrm{N})$. All the rats were starved for $\mathrm{I} d$. The values are for seven, seven and eight animals, respectively, and the bars indicate sEM. The $P$ values give the statistical significance of uptake or output by the method of paired comparisons: ${ }^{*}<0.05$; ${ }^{*} P<0.01 ; * * * P<0.001$. A statistical comparison between the different groups of animals is given in Table $I$. 
Vol. 27

Blood and liver amino acids in diabetes

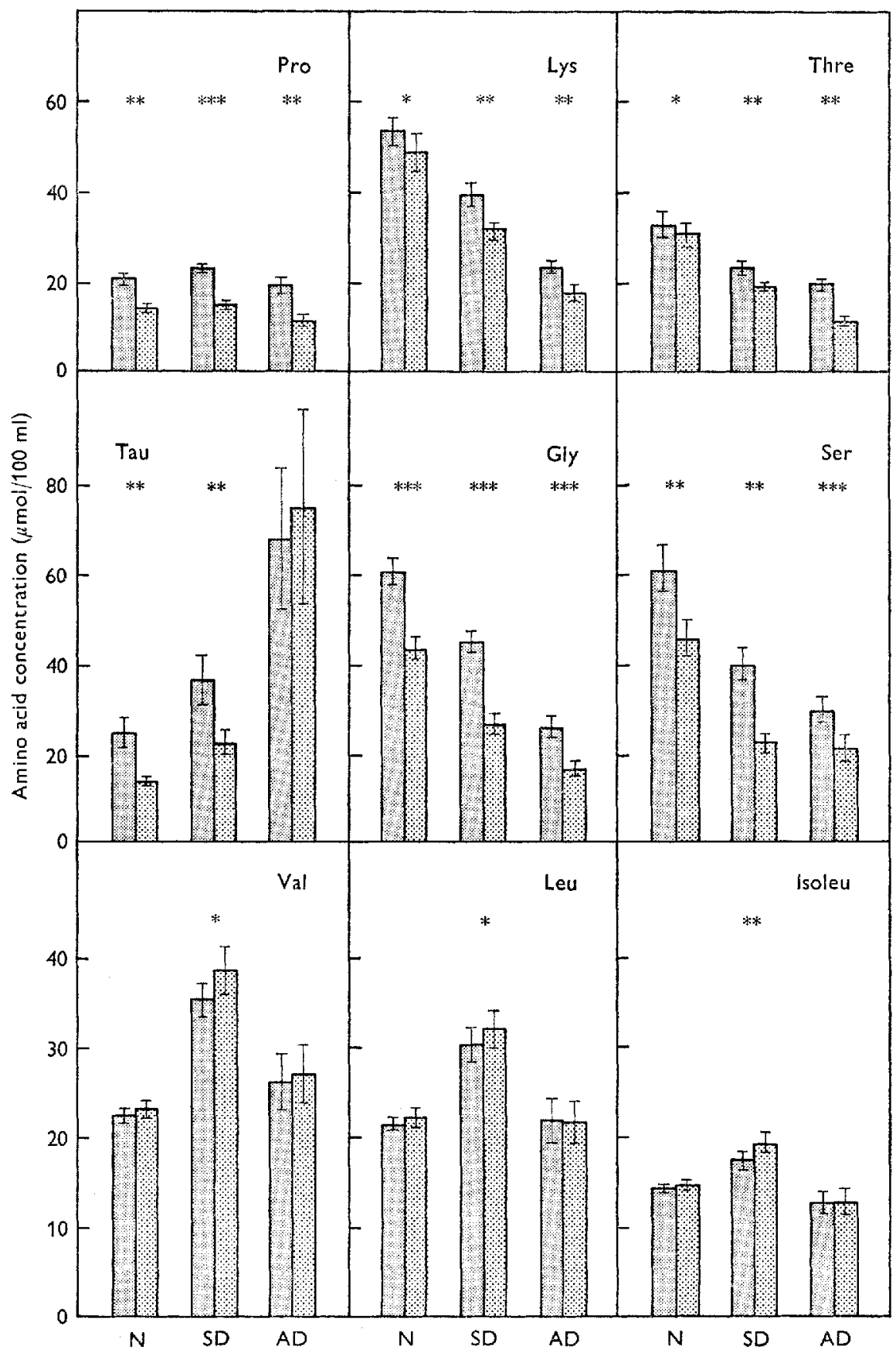

Fig. I (continued). For legend see opposite. 


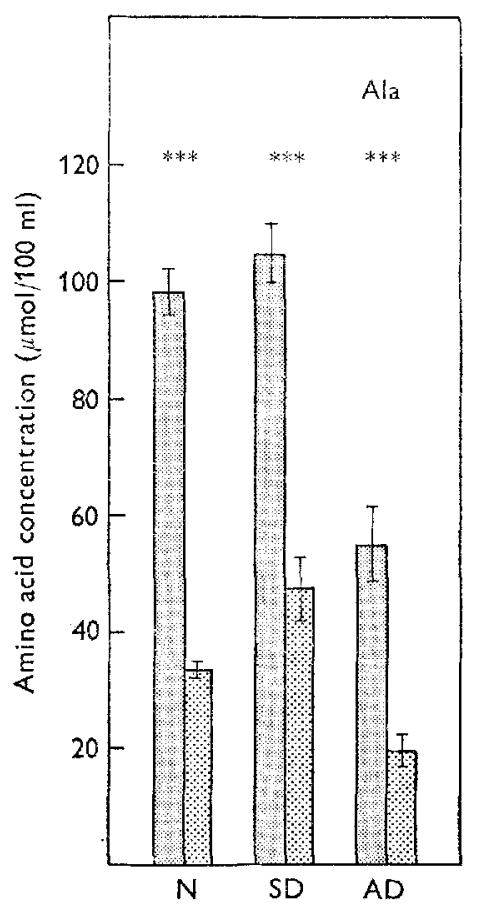

Fig. I (continued). For legend see p. $25^{\circ}$.

a $40 \mathrm{mg} / \mathrm{ml}$ solution in $0.07 \mathrm{M}$-sodium citrate buffer, $\mathrm{pH} 4.5$, within 5 min of being prepared), or by intraperitoneal injection of alloxan (Koch-Light Laboratories), $200 \mathrm{mg} / \mathrm{kg}$ (as a $68 \mathrm{mg} / \mathrm{ml}$ solution in a similar buffer, within $5 \mathrm{~min}$ of being prepared). The streptozotocin-treated animals were kept for $7-9 \mathrm{~d}$ before the experiments and the alloxan-treated animals were kept for $2 \mathrm{~d}$. Food, previously available with water ad lib., was withdrawn from all groups of animals during the final $\mathrm{I} 8-2,2 \mathrm{~h}$ to eliminate immediate effects on amino acid pools of the increased food intake of the diabetic animals. It was found difficult to maintain rats made strongly diabetic with alloxan in reasonable condition for longer than about $2 \mathrm{~d}$. Criteria of satisfactory diabetes were a blood glucose concentration of over $200 \mathrm{mg} / \mathrm{ro0} \mathrm{ml}$ as judged by Dextrostix strips (Ames Company) and a positive indication of glucose in the urine (Clinistix; Ames Company). The streptozotocin diabetic rats lost 50-70 g body-weight between the time of injection of streptozotocin and the morning of the experiment. The control rats were fasted for $\mathrm{I} \mathrm{d} \mathrm{(18-22} \mathrm{h)} \mathrm{and} \mathrm{weighed} 25^{\circ}-29^{\circ} \mathrm{g}$ before withdrawal of food.

Blood and liver sampling methods. These were as described previously (Bloxam, I972).

Determinations of amino acid and DNA concentrations. These methods were as described previously (Bloxam, 1972).

Results are expressed as the mean values with their standard errors. 
RESULTS

Effects of diabetes on plasma amino acid concentrations after $\mathbf{I} d$ starvation. Fig. I shows amino acid concentrations in plasma of blood from the portal and hepatic veins of streptozotocin diabetic and alloxan diabetic rats and these are compared with values for normal rats. A statistical comparison of the portal and venous concentrations in the different groups is given in Table $\mathbf{I}$.

Table I. Statistical comparison of results in Fig. I

\begin{tabular}{|c|c|c|c|c|c|c|}
\hline \multirow[b]{3}{*}{ Amino acid } & \multicolumn{6}{|c|}{$t$ test probability value $(P)$} \\
\hline & \multicolumn{2}{|c|}{$\begin{array}{c}\text { Streptozotocin } \\
\text { diabetic } \\
v . \\
\text { normal }\end{array}$} & \multicolumn{2}{|c|}{$\begin{array}{c}\text { Alloxan } \\
\text { diabetic } \\
v . \\
\text { normal }\end{array}$} & \multicolumn{2}{|c|}{$\begin{array}{c}\text { Streptozotocin } \\
\text { diabetic } \\
v . \\
\text { alloxan diabetic }\end{array}$} \\
\hline & HP & HV & HP & $\mathrm{HV}$ & $\mathrm{HP}$ & HV \\
\hline Taurine & NS & $<0.02$ & $<0.05$ & $<0.02$ & NS & $<0.05$ \\
\hline Aspartate & $\mathrm{NS}$ & NS & NS & NS & $<0.10$ & NS \\
\hline Threonine & $<0.05$ & $<0.0 I$ & $<0.0 \mathrm{I}$ & $<0.001$ & $<0.10$ & NS \\
\hline Serine & $<0.05$ & $<0.01$ & $<0.01$ & $<0.01$ & NS & NS \\
\hline Glutamate & $<0.10$ & $<0.001$ & $<0.0 \mathrm{I}$ & NS & $<0.10$ & $<0.05$ \\
\hline $\begin{array}{l}\text { Proline } \\
\text { Pro }\end{array}$ & NS & NS & NS & NS & NS & $\mathrm{NS}$ \\
\hline Citrulline & $<0.001$ & $<0.001$ & NS & NS & $<0.05$ & NS \\
\hline Glycine & $<0.01$ & $<0.00 \mathrm{I}$ & $<0.001$ & $<0.00 x$ & $<0.00 \mathrm{I}$ & $<0.02$ \\
\hline Alanine & NS & $<0.05$ & $<0.001$ & $<0.01$ & $<0.001$ & $<0.01$ \\
\hline$\alpha$-Aminobutyrate & $<0.00 \mathrm{I}$ & NS & $<0.01$ & $<0.01$ & $<0.001$ & $<0.00$ \\
\hline Cystine & NS & $<0.01$ & $<0.01$ & $<0.01$ & $<0.05$ & NS \\
\hline Methionine & $<0.10$ & NS & $<0.10$ & $<0.01$ & $<0.0 \mathrm{I}$ & $<0.0 \mathrm{I}$ \\
\hline Tyrosine & NS & NS & $<0.05$ & $<0.01$ & $<0.01$ & $<0.02$ \\
\hline Phenylalanine & NS & NS & $<0.01$ & $<0.01$ & $<0.01$ & $<0.05$ \\
\hline Ornithine & NS & $<0.05$ & NS & $\mathrm{NS}$ & $<0.05$ & NS \\
\hline Lysine & $<0.0 I$ & $<0.0 \mathrm{I}$ & $<0.001$ & $<0.001$ & $<0.00 \mathrm{~T}$ & $<0.00$ \\
\hline Histidine & NS & $<0.01$ & NS & NS & NS & $<0.10$ \\
\hline Tryptophan & $<0.02$ & $<0.001$ & $<0.001$ & $<0.00 \mathrm{I}$ & $<0.01$ & $<0.0 \mathrm{r}$ \\
\hline Arginine & NS & $<0.05$ & $<0.001$ & $<0.01$ & $<0.001$ & NS \\
\hline Valine & $<0.001$ & $<0.00 \mathrm{I}$ & $\mathrm{NS}$ & $\mathrm{NS}$ & $<0.05$ & $<0.05$ \\
\hline Leucine & $<0.01$ & $<0.01$ & NS & NS & $<0.05$ & $<0.02$ \\
\hline Isoleucine & 0.02 & $<0.0 I$ & NS & NS & $<0.05$ & $<0.02$ \\
\hline
\end{tabular}

HP, comparison of amino acid concentrations in hepatic portal blood.

HV, comparison of amino acid concentrations in hepatic venous blood. NS, $P>0.10$.

Many amino acids in the plasma of the diabetic rats were lower in concentration than in normal rats. In streptozotocin diabetic rats, amino acids significantly lower in both portal and venous blood were glutamate, threonine, serine, glycine, lysine and tryptophan; those significantly lower in venous blood but not in portal blood were histidine, arginine and ornithine. Those whose concentrations were not significantly changed in either portal or venous blood were aspartate, proline, tyrosine and phenylalanine. On the other hand, citrulline, valine, leucine and isoleucine, and probably also taurine (though not significantly) were raised in both portal and venous blood. The concentration of methionine was higher in portal blood but not changed. 
in venous blood compared with the controls, and the levels of alanine and cystine were higher in venous but not in portal blood.

The pattern of changes in alloxan diabetes was generally similar to that in streptozotocin diabetes but in many instances the changes were much more pronounced. There were, however, some qualitative differences. Histidine and $\alpha$-aminobutyrate concentrations were raised in alloxan diabetes rather than lowered as in streptozotocin diabetes, and those of citrulline, valine, leucine and isoleucine were unchanged instead of raised.

Amino acid movements in diabetes. Comparison of the portal-venous amino acid differences (Fig. I) of the diabetic rats with those in the normal control animals shows that the direction of flow of the amino acids was in almost every instance the same as in the normal rats, but in the streptozotocin diabetic rats the values of the differences were greater than in the controls for most of the acids, whether taken up by the liver or given out, namely aspartate, glutamate, methionine, tyrosine, histidine, arginine, taurine, proline, threonine, serine, glycine, lysine, cystine, valine, leucine and isoleucine. However, statistically, the portal-venous differences were significantly greater only for methionine $(P<0.02)$, arginine $(P<0.05)$, cystine $(P<0.01)$, isoleucine $(P<0.02)$, and approached significance for valine and leucine $(P<0.10)$, histidine $(P=0.10)$ and perhaps glutamate $(P<0 \cdot 20)$. Whether these results can be interpreted as indicating an increased rate of uptake and output respectively of these acids in streptozotocin diabetes is discussed later. The amino acids whose portal-venous differences in concentration were not changed in the diabetic group of rats were phenylalanine, citrulline and alanine, and the portal-venous difference of ornithine was decreased $(P<0.05)$. The outputs by the liver of $\alpha$-aminobutyrate and tryptophan were abolished altogether in the diabetic group (the values for reduction in portal-venous differences in streptozotocin diabetes being significant, $P<0.00 \mathrm{I}$, for tryptophan).

Generally, increased portal-venous differences as were found for the streptozotocin diabetic rats are not seen in the alloxan diabetic animals, but it is difficult to draw conclusions from this because most of the livers were grossly fatty and many appeared to be damaged. It is known that alloxan causes liver damage (Lukens, 1948). Some amino acids, notably taurine, were found to be leaking from the damaged livers while the uptake of some of the others was diminished, indicating that the concentrative ability of these livers for some of the amino acids was impaired. From one badly damaged liver, not included in the results given here, all the amino acids except aspartate, glutamate and proline were found to be leaking.

Changes in liver amino acid concentrations in diabetes. Table 2 shows the concentrations of amino acids in livers from streptozotocin and alloxan diabetic rats expressed relative to wet weight of liver, compared with their concentrations in livers from normal rats. A statistical comparison of the values in the different groups of animals is given in Table 3 .

There are few measurements in the literature of concentrations of amino acids in the diabetic rat liver. These are confined to livers of fed alloxan diabetic rats. The changes found here caused by alloxan diabetes in livers of rats starved for $\mathrm{I} d$, expressed 
per wet weight (Table 2), are on the whole similar to those found for selected amino acid by Clark, Yamada \& Swendseid (1968) and by Williamson, Lopes-Vieira \& Walker $(1967)$ in fed rats but rather less in agreement with those reported by Kirsten, Kirsten, Hohorst \& Bücher ( $196 \mathrm{r}$ ) in fed rats. These workers found falls in the concentrations of alanine, threonine, serine, tyrosine, phenylalanine and lysine compared with no change or increases observed here, and no change in the concentrations of histidine, proline, valine, leucine and isoleucine compared with increases here.

Table 2. Concentrations ( $\mu$ mol/ $/ \mathrm{roo} g$ wet weight) of amino acids in livers of streptozotocin diabetic and alloxan diabetic rats compared with livers of normal rats

(Mean values with their standard errors)

\begin{tabular}{|c|c|c|c|}
\hline Amino acid & Normal & $\begin{array}{c}\text { Streptozotocin } \\
\text { diabetic }\end{array}$ & Alloxan diabetic \\
\hline Taurine & $509^{2} \pm 39^{-2}$ & $342 \cdot 3 \pm 105 \cdot 5$ & $346 \cdot 4 \pm 54 \cdot 3$ \\
\hline Aspartate & $120.0 \pm 5.8$ & $130.5 \pm 14.2$ & $55.8 \pm 6.0$ \\
\hline Threonine & $44^{\circ} \pm 2 \cdot 7$ & $28 \cdot x \pm 2 \cdot 5$ & $4 I \cdot 6 \pm 5 \cdot 6$ \\
\hline Serine & $86 \cdot 3 \pm 9 \cdot 3$ & $44 \cdot I \pm 2 \cdot I$ & $62 \cdot 9 \pm 9 \cdot 9$ \\
\hline Glutamate & $134 \cdot 3 \pm 8 \cdot 0$ & $180.6 \pm 15.9$ & $60 \cdot 3 \pm 5 \cdot 5$ \\
\hline Proline & $18 \cdot 0 \pm 2 \cdot 3$ & $193 \pm 24$ & $4 \mathrm{I} \cdot 3 \pm 5 \cdot 8$ \\
\hline Citrulline & $7.0 \pm 0.4$ & $10 \cdot 1 \pm 1 \cdot 6$ & $85 \cdot 0 \pm 27 \cdot 6$ \\
\hline Glycine & $249^{\circ} 0 \pm 18 \cdot 1$ & $186 \cdot 7 \pm 8 \cdot 9$ & $88 \cdot 0 \pm 9 \cdot 8$ \\
\hline Alanine & $42 \cdot 7 \pm 7 \cdot 8$ & $79 \cdot 8 \pm 15 \cdot 2$ & $149.7 \pm 46 \cdot 6$ \\
\hline$\alpha$-Aminobutyrate & $2.5 \pm 0.3$ & $\mathrm{I} \cdot 8 \pm 0.2$ & $27 \cdot 6 \pm 12.4$ \\
\hline Cystine & $<0.7$ & $<0.9$ & $0.9 \pm 0.2$ \\
\hline Methionine & $13 \cdot I \pm I \cdot 0$ & $14.9 \pm 0.7$ & $21 \cdot 5 \pm 5 \cdot 4$ \\
\hline Tyrosine & $8.9 \pm 0.5$ & $10 \cdot 0 \pm x \cdot 3$ & $13 \cdot 3 \pm 1 \cdot 8$ \\
\hline Phenylalanine & $5.4 \pm 0.5$ & $6.7 \pm 0.6$ & $5 \cdot 4 \pm 0.7$ \\
\hline Ornithine & $15 \cdot 3 \pm 1 \cdot 3$ & $21 \cdot 9 \pm 2 \cdot 5$ & $28 \cdot 1 \pm 4 \cdot 2$ \\
\hline Lysine & $58.8 \pm 3 \cdot 8$ & $62 \cdot 0 \pm 3 \cdot 8$ & $133 \cdot 8 \pm 5^{1} \cdot 5$ \\
\hline Histidine & $47 \cdot 2 \pm 2 \cdot 0$ & $43 \cdot 3 \pm 4 \cdot 2$ & $88.0 \pm 13.9$ \\
\hline Tryptophan & $2 \cdot 7 \pm 0.3$ & $2 \cdot 1 \pm 0.3$ & $I .4 \pm 0.2$ \\
\hline Arginine & $5 \cdot 8 \pm 0.3$ & $5.9 \pm 0.2$ & $15 \cdot 9 \pm 4 \cdot 6$ \\
\hline Valine & I5.9土I-2 & $31 \cdot 9 \pm 3 \cdot 0$ & $38 \cdot 5 \pm 5 \cdot 2$ \\
\hline Leucine & $I 4 \cdot 2 \pm I \cdot I$ & $27 \cdot 0 \pm 2 \cdot 1$ & $28 \cdot 8 \pm 35$ \\
\hline Isoleucine & $9 \cdot 0 \pm 0.6$ & $I 6 \cdot I \pm I \cdot 2$ & $15 \cdot 1 \pm 2 \cdot 0$ \\
\hline
\end{tabular}

All three groups of rats were starved for I $\mathrm{d}$ (see p. 234). The values for livers of streptozotocin diabetic, alloxan diabetic and normal rats were from seven, six and nine animals, respectively.

Considering first the streptozotocin diabetic animals, the concentrations of the essential amino acids were generally increased, particularly of the branched-chain group. A notable exception was the decreased concentration of the glucogenic threonine. Aspartate (not statistically significant), glutamate and alanine, which are particularly connected with carbohydrate metabolism, and the urea cycle intermediates, citrulline, ornithine and arginine, were also increased in concentration. Of the remaining amino acids there was no significant change in the concentration of taurine, $\alpha$-aminobutyrate and proline and falls in those of glycine and serine.

The changes in the alloxan diabetic rats were to some extent similar to those in the streptozotocin diabetic animals, though for some amino acids the trends were much more pronounced. For example, the concentrations of alanine, citrulline, arginine, histidine, proline and lysine were greatly increased while that of glycine was consider- 
ably decreased. On the other hand, those of aspartate and glutamate were decreased instead of increased as they were in the streptozotocin diabetic group, those of tryptophan were decreased and those of $\alpha$-aminobutyrate were increased instead of not changing, and those of threonine were not changed instead of decreasing (see Tables 2,3). The amount of amino acid per unit of DNA is a measure of the pool size per cell rather

Table 3. Statistical comparison of the amino acid concentrations in Table 2

\begin{tabular}{|c|c|c|c|}
\hline & \multicolumn{3}{|c|}{$t$ test probability value $(P)$} \\
\hline & $\begin{array}{c}\text { Streptozotocin } \\
\text { diabetic } \\
v . \\
\text { normal }\end{array}$ & $\begin{array}{c}\text { Alloxan } \\
\text { diabetic } \\
v . \\
\text { normal }\end{array}$ & $\begin{array}{c}\text { Streptozotocin } \\
\text { diabetic } \\
v . \\
\text { alloxan diabetic }\end{array}$ \\
\hline Taurine & NS & $<0.05$ & NS \\
\hline Aspartate & NS & $<0.001$ & $<0.01$ \\
\hline Threonine & $<0.0 I$ & NS & $<0.10$ \\
\hline Serine & $<0.01$ & NS & NS \\
\hline Glutamate & $<0.05$ & $<0.00 \mathbf{I}$ & $<0.001$ \\
\hline Proline & NS & $<0.01$ & $<0.01$ \\
\hline Citrulline & $<0.10$ & $<0.0 x$ & $<0.05$ \\
\hline Glycine & $<0.02$ & $<0.001$ & $<0.001$ \\
\hline Alanine & $<0.05$ & $<0.05$ & NS \\
\hline$\alpha$-Aminobutyrate & $<0.10$ & $<0.10$ & $<0.10$ \\
\hline Cystine & - & - & - \\
\hline Methionine & NS & NS & NS \\
\hline Tyrosine & NS & $<0.05$ & NS \\
\hline Phenylalanine & NS & NS & NS \\
\hline Ornithine & $<0.05$ & $<0.0 I$ & NS \\
\hline Lysine & NS & NS & NS \\
\hline Histidine & NS & $<0.0 \mathrm{I}$ & $<0.02$ \\
\hline Tryptophan & NS & $<0.01$ & $<0 .{ }_{10}$ \\
\hline Arginine & NS & $<0.05$ & $<0.10$ \\
\hline Valine & $<0.001$ & $<0.001$ & NS \\
\hline Leucine & $<0.001$ & $<0.001$ & NS \\
\hline Isoleucine & $<0.001$ & $<0.01$ & NS \\
\hline
\end{tabular}

Table 4. Effect of streptozotocin and alloxan diabetes on liver weight relative to DNA in rats starved for $\mathrm{I} d$

(Mean values, with their standard errors, for eight rats)

$$
\text { Normal Streptozotocin diabetic Alloxan diabetic }
$$

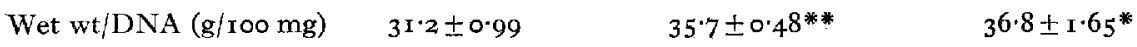

* Significantly different from the value for the liver of the normal rat $(P<0.02)$.

** Significantly different from the value for the liver of the normal tat $(P<0.01)$.

than concentration. If the quantities of amino acids relative to DNA are calculated using the results in Table 4 it can be seen that, assuming the DNA content per cell is not altered in diabetes, the pool sizes are increased relative to concentrations in both types of diabetes. The significance of the amino acid changes in livers of diabetic rats is discussed later. 
By comparing the changes in amino acid concentrations in the liver (Tables I and 2) with changes in their concentrations in the blood (Fig. I) it can be seen that the changes in the blood were not paralleled by similar changes in the liver, except for increases in the concentrations of methionine, citrulline, valine, leucine and isoleucine and falls in the concentrations of threonine, serine and glycine in the streptozotocin diabetic animals, and increases in $\alpha$-aminobutyrate and histidine and falls in serine, glycine, glutamate and tryptophan in the alloxan diabetic animals.

\section{DISCUSSION}

Reports on the effects of diabetes on blood amino acid concentrations in rat, dog and man are rather variable (Scharff \& Wool, I966; Clark et al. I 968; Ivy, Svec \& Freeman, 195r; Carlsten \& Werkö, r967). Scharff \& Wool (1966) found that the effects vary according to the method of induction of the diabetes, but one relatively consistent feature in different types of diabetes has been an increased concentration of each of the branched-chain amino acids, valine, leucine and isoleucine. In the fed alloxan diabetic rat these increases were found to be very large (Clark et al. 1968; Scharff \& Wool, 1966), but here in the streptozotocin diabetic rat starved for $\mathrm{I} d$ the increases, though statistically significant, were much smaller and in the alloxan diabetic rat starved for $I \mathrm{~d}$ there was no increase. This difference between the fed and starved diabetic rat may be connected with the apparent absence for the branched-chain acids of the homoeostatic type of control which the perfused liver seems to exert over the concentrations of the others (Bloxam, I971). In vivo the branched-chain amino acids are not removed from the blood by the liver in the fed rat (Bloxam, 1972); indeed, in man and in the dog their blood concentrations after ingestion of protein are raised to a greater extent and for a longer period than those of the others (Frame, 1958; Elwyn, Parikh \& Shoemaker, I968). Thus the greatly increased food intake of the diabetic animals may well have led to the substantially elevated blood concentrations of this group whereas in the starved diabetic rat the immediate effect of increased food intake would not be operative. The total lack of increase in the concentrations of the branchedchain amino acids in the alloxan diabetic animals compared with those with streptozotocin diabetes is no doubt related to the fact that in the former there was no output of these amino acids, whereas in the latter they were given out to a statistically significant extent. (See Fig. I and Table r.)

Amino acid movements in the diabetic rat. With the blood sampling method used, it is not possible precisely to quantify rates of flow of amino acids to and from the liver for reasons discussed previously (Bloxam, I972). Even a non-quantitative estimate from the results in Fig. I of relative rates of movement depends on whether the rate of flow of blood through the liver is appreciably altered in diabetes. The little information there is in the literature indicates that neither diabetes mellitus in man (Bearn, Billing \& Sherlock, 1952) nor administration of insulin in the rat, dog or man (Grayson \& Kinnear, 1958; Shoemaker, Mahler, Ashmore \& Pugh, I959; Bearn et al. 1952) affects hepatic blood flow. Therefore substantial changes in portal-venous differences are tentatively taken to indicate changes in rates of amino acid movement. 
The direction of flow of the amino acids was not changed in diabetes, except for tryptophan, whose output was abolished in both types of diabetes, and the branchedchain amino acids, whose output was abolished in alloxan diabetes although apparently enhanced in streptozotocin diabetes. In streptozotocin diabetes the portal-venous differences were for many of the amino acids considerably increased, suggesting that the rates of flow of the relative groups to and from the liver were accelerated, subject to the provisos in the previous paragraph. The generally lower blood concentrations of the amino acids which are taken up by the liver, together with their increased liver concentrations, imply that the liver in the streptozotocin diabetic rat concentrates amino acids more strongly than in the normal rat. A similar but less marked tendency was found during starvation (Bloxam, 1972). Since there is some evidence from other workers that insulin enhances the concentration of amino acids by the perfused rat liver (Chambers, Georg \& Bass, 1965; Mondon \& Mortimore, 1967), this effect of diabetes is not likely to be due to the lack of insulin itself, but is more probably due to the altered secretion or activity of other hormones. For instance, in diabetes, as well as a decrease in circulating insulin, there is some evidence of increased secretion of glucocorticoids (Morita \& Orten, 1950; Kalant, 1955; Stowers, 1951), which are believed to increase the concentration of amino acids by the liver (Christensen, I964; Noall, Riggs, Walker \& Christensen, 1957; Chambers et al. 1965). In addition, glucagon, which also enhances the uptake of amino acids by the liver, would be acting without the antagonism of insulin (see Jefferson, Exton, Butcher, Sutherland \& Park, 1968; Exton, Jefferson, Butcher \& Park, 1966). This general picture is in accord with the current idea that, after increased uptake of amino acids by muscle and their incorporation into muscle protein under the influence of insulin during the absorption of food, insulin concentrations subsequently fall and corticosteroid levels rise, causing breakdown of muscle protein and release into the blood of amino acids which flow to the liver (see, for instance, the review of Munro, 1964). The picture is less clear for the alloxan diabetic rats where it appears that alloxan has effects on tissues other than its diabetogenic action (see below).

Liver amino acids in diabetes. Kirsten et al. (1961) found in their experiments that the levels of alanine, aspartate, serine and threonine were reduced in the livers of fed alloxan diabetic rats to approximately the same extent as the cytoplasmic $\mathrm{NAD}^{+}: \mathrm{NADH}$ ratio estimated from the ratios lactate:pyruvate, malate:oxaloacetate and glycerol-Iphosphate: dihydroxyacetone phosphate. They suggested that the falls in the concentrations of these acids on induction of the diabetes reflected the change in the cytoplasmic redox state of the cells. Here, in livers of alloxan diabetic rats starved for I $d$ the concentrations of aspartate and serine were reduced but that of alanine was greatly increased. In the streptozotocin diabetic rats serine and threonine were reduced in concentration but alanine and aspartate were increased (aspartate not statistically significantly). This indicates that the picture is rather more complex than that suggested by these workers.

Comparison between alloxan and streptozotocin diabetes. Although the changes in amino acid pattern in blood and liver caused by the two types of diabetes were to some extent similar, there were also some marked differences which cannot be interpreted 
simply. It is possible that these differences were due to the different stage of diabetogenesis reached when the rats were killed. The alloxan diabetic animals were kept for $2 \mathrm{~d}$ after injection and the streptozotocin diabetic animals for $7-9 \mathrm{~d}$ (see p. 252). Indeed, large quantities of lipid were apparent in the blood and liver of the alloxantreated rats whereas the streptozotocin-treated ones appeared to be clearer of lipid than the normal group. On the other hand, substantial differences in carbohydrate metabolism of muscle have been found in rats treated with the two diabetogenic agents (Mansford \& Opie, I968; Beloff-Chain \& Rookledge, 1968), although some of these may again be connected with the stage of production of diabetes reached. Moreover, the diabetes induced by alloxan is complicated by side-effects of the drug, including liver damage (Lukens, I948), whereas the changes caused by streptozotocin appear to be more nearly due solely to its effects on the pancreatic $\beta$-cells (Dulin, Lund \& Gerritsen, 1967; Arison, Ciaccio, Glitzer, Cassara \& Pruss, 1967 ). This is consistent with the more complex nature of the changes in amino acid pattern due to administration of alloxan found here.

I am grateful to M. I. Khan for carrying out some of the amino acid analyses.

\section{REFERENCES}

Arison, R. N., Ciaccio, E. I., Glitzer, M. S., Cassara, J. A. \& Pruss, M. P. (I967). Diabetes r6, 5 I. Bearn, A. G., Billing, B. \& Sherlock, S. (r952). Clin. Sci. Ir, I 5 r.

Beloff-Chain, A. \& Rookledge, K. A. (1968). Biochem. F. 110, 529.

Bloxam, D. L. (1971). Br. F. Nutr. 26, 393.

Bloxam, D. L. (1972). Br. F. Nutr. 27, 233.

Carlsten, A. \& Werkö, L. (I967). Acta med. scand. 181, I99.

Chambers, J. W., Georg, R. H. \& Bass, A. D. (1965). Molec. Pharmac. 1, 66.

Christensen, H. N. (1964). In Mammalian Protein Metabolism Vol. I, p. 105 [H. N. Munro and J. B. Allison, editors]. New York and London: Academic Press.

Clark, A. J., Yamada, C. \& Swendseid, M. E. (1968). Am. F. Physiol. 215, 1324.

Dulin, W. E., Lund, G. H. \& Gerritsen, G. C. (1967). Diabetes r6, 5 I2.

Elwyn, D. H., Parikh, H. C. \& Shomaker, W. C. (1968). Am. F. Physiol. 215, 1260.

Exton, J. H., Jefferson, L. S., Butcher, R. W. \& Park, C. R. (I966). Am. F. Med. 40, 709.

Frame, E. G. (1958). F. clin. Invest. 37, 17 10.

Grayson, J. \& Kinnear, T. (1958). F. Physiol., Lond. $\mathbf{x 4 4}^{2}, 5^{2 .}$

Ivy, J. H., Svec, M. \& Freeman, S. (1951). Am. F. Physiol, 167, I82.

Jefferson, L. S., Exton, J. H., Butcher, R. W., Sutherland, E. W. \& Park, C. R. (rg68). F. biol. Chem. 243, 1031 .

Kalant, N. (1955). Am. F. Physiol. 182, 503.

Kirsten, E., Kirsten, R., Hohorst, H. J. \& Bïcher, T. (1961). Biochem. biophys. Res. Commun. 4, I69.

Lukens, F. D. W. (1948). Physiol. Rev. 28, 304.

Mallette, L. E., Exton, J. H. \& Park, C. R. (1969). 7. biol. Chem. 244, 5724.

Manchester, K. L. (1970). In Diabetes Mellitus: Theory and Practice Ch. 2, p. 28 [M. Ellenberg and H. Rifkin, editors]. New York: McGraw-Hill.

Mansford, K. R. L. \& Opie, L. (I968). Lancet i, 670.

Mondon, C. E. \& Mortimore, G. E. (1967). Am. F. Physiol. 212, I73.

Morita, Y. \& Orten, J. M. (1950). Am. F. Physiol. I6r, 545.

Munro, H. N. (1 964). In Mammalian Protein Metabolism Vol. I, p. $3^{82}$ [H. N. Munro and J. B. Allison, editors]. New York and London: Academic Press.

Noall, M. W., Riggs, 'T. R., Walker, L. M. \& Christensen, H. N. (I957). Science, N. Y. 126, 1002.

Scharff, R. \& Wool, I. G. (I966). Biochem. f. 99, I73.

Shoemaker, W. C., Mahler, R., Ashmore, J. \& Pugh, D. E. (1959). Am. F. Physiol. 196, I250.

Stowers, J. M. (1951). Clin. Sci. 10, 487.

Williamson, D. H., Lopes-Vieira, O. \& Walker, B. (I967). Biochem. F. 104, 497. 